\title{
Human Development in a Globalized World. Education towards Peace, Cultural Diversity and Sustainable Development
}

\author{
by Christoph WULF \\ Freie Universität Berlin (Germany)
}

\section{Introduction}

While the future is unbeknown to human beings, it is highly relevant as the horizon of education. Children and youths are to develop with a view to being fit for the future. Even if many aspects that will contribute to education in the future cannot be specified, there is no doubt that peace (1), cultural diversity (2) and sustainability (3) are essential conditions. All three of these areas are intertwined.

\section{Education for Peace}

The Education For All Monitoring Report on "The hidden crisis. Armed conflict and education", commissioned and published by UNESCO 2011 makes it very clear: armed conflicts and conditions of violence prevent children from learning. Education can only unlock its full potential if there is "freedom of fear". Absence of violence is a prerequisite of education. Education for Peace has to be a central element in a future-oriented education.
Violence between people of different societies and cultures is unavoidable if images of the other, which help communicate perspectives of historical and cultural diversity as conditions of Europeanization and globalization, do not become an integral part of education. This was shown in the violent history of the $20^{\text {th }}$ century. Critical examination of the different forms of violence and the possibilities for peace is therefore a central task of education. Due to the existence of modern weapons of mass destruction, human beings still face an unprecedented threat of war and violence. Peace has become the prime condition for human life. Its production and preservation is the key not only to the survival of individuals, generations and nations, but also to the survival of humanity as a whole. In the context of education, it is therefore imperative that curricula both cover the conditions that lead to war, violence and destruction and the search for ways of rendering them less harmful or even overcoming them. 
Education for peace is the contribution of education to overcoming conditions of violence. It recognizes that these are often due to systemic problems and can only be reduced in part by education. Education concerning peace is based on the idea that a constructive manner of dealing with the major problems currently facing humanity must be part of a lifelong learning process that begins in childhood and continues throughout adult life.

In the early 1970s, peace research elaborated on the fact that peace could not be brought about by a change in consciousness alone. The experiences of the peace movement have confirmed these analyses. The absence of peace and the presence of violence are too deeply rooted in social structures to be overcome by human striving for peace alone. Peace requires additional political action directed at reducing the violent structures inherent to the international system and to society at large.

Education for peace must draw on central guiding ideas such as organized lack of peace, structural violence and social justice. These ideas emphasize the social character of peace and guard us from fantasies of omnipotence and naïve problem reductions. According to Galtung's differentiation, which is still valid today, peace not only denotes the absence of war and direct violence (a negative definition of peace), but also needs to be understood as the reduction of structural violence and the production of social justice (a positive definition of peace). According to this understanding of peace, education must not only tackle war and direct violence between nations and ethnic groups, but also address the violent conditions at the base of society (Wulf 2008, 1973, 1974; Galtung 1973; Senghaas 1995, 2000; Frieters-Reermann 2009).

Education towards peace condemns both organized open violence and structural violence. As an alternative, it promotes processes of non-violent conflict resolution, the realization of social justice and the improvement of co- and self-determination. It is conscious of the fact that this is a process rather than a state and that, despite its apparent unattainability, peace must remain its unconditional objective.

Overcoming both apathy and experiences of powerlessness is the precondition for any peace-related learning process that can pave the way for a disposition to act. One way to learn consists of linking one's own experiences of deficiency with major global problems. The insight that certain macro-structural conflict formations determine and even endanger one's own life leads to a motivation to champion peace. Thus, beyond imparting relevant insights, education can bring about changes in attitude and promote political commitment, both of which lead to changes in political action.

Education for peace requires the establishment of certain standards if it is to further non-violent learning processes. It will also develop forms of participatory and autonomous learning. These learning processes place great responsibility for initiative in the hands of the recipients of the teaching of history. They are encouraged to develop their visions of peace and a consciousness of the historical causes 
and the general changeability of conflict formations; this contributes to the conception and development of blueprints for changing the world. At the same time, it ensures that education and people's perception of problems are oriented towards the future.

\section{One-World Mentality vs. Cultural Diversity}

Globalization must be understood as a process in which two global tendencies that define the present are advancing reciprocally in a manner that is not without conflict. One tendency is towards homogenization and universal standardization of the world; the other tendency is towards provision of room for cultural diversity in this process. Both tendencies also create new forms of globalization. The mission of future- oriented education is to develop recognition and esteem of the other and of alterity in a manner that is free of violence. Within the scope of this education, the terms differentiation, transformation and hybrid formation play a central role in dealing with the foreign, the other and alterity. In education it is important to make use of these three concepts for the analysis of cultural phenomena and relations. Learning, which is oriented towards a better understanding of the other and towards a reduction in violence towards other people and future generations, will also have to develop innovative forms of learning.

Globalization is a complex phenomenon which has a profound influence on the lifestyles and self concepts of many human beings. Globalization is now all-pervasive in almost all areas of life, with the result that the effects of critical situations such as the current crisis of the financial markets and banks are exerted not only nationally, but worldwide. Among many other aspects, the following six dimensions are of constitutive importance for the process of globalization (Wulf/Merkel 2002):

- international financial and capital markets, the mobility of capital and the increasing influence of neoliberal economic theory;

- company strategies and markets with global strategies of production, distribution and cost minimization by means of outsourcing;

- transnational political bodies and the declining influence of the nation state;

- patterns of consumption, lifestyles and cultural styles and their tendency towards uniformity;

- the new media and tourism; research, development and technology;

- the one-world mentality.

To these characteristics we must also add the globalization of poverty, suffering, war, terror and the exploitation and destruction of nature, which are related to colonialism and capitalism and have long been ignored. These developments are leading to a separation of the political from the economic spheres, to a globalization of lifestyles and to a rising importance of new communication media. These are no linear processes. They are disrupted in many 
places and produce contradictory results. They have different objectives and decision-making structures and are organized in networks, like rhizomes. They do not run parallel in space or time and they are subject to a wide variety of different dynamic forces. They are multi-dimensional and multi-regional and deeply rooted in the centers of neoliberal capitalism. The dominance of a globalized economy over political life and the globalization of lifestyles by means of the increasing presentation of experience as images in the new media help to bring about changes in the way we work. All this has been accompanied by a decline in the influence of the individual nation states, while cultures have become increasingly permeable and homogeneous, resulting in the development of new ways and spheres of life.

The question arises as to what this scenario means for education and to what extent education takes these developments suitably into account. Whatever the case may be, there is now a strong need for discussion in education about the development of and changes associated with globalization. This discussion is leading to a partial re-organization of ways of education, with an associated reduction in the reliance on national culture as explanatory basis.

The challenges of globalization have made it necessary to conduct a thorough investigation into the conditions of human life as they stand today. This is the task of a contemporary anthropology, which can no longer be reduced to ethnology, philosophical anthropology or anthropological issues in the historical sciences, but must be refor- mulated as historical and cultural anthropology. Thus defined, anthropology must set itself the task of elaborating a body of knowledge that makes a contribution to improving human beings' understanding of themselves and the world and takes cultural diversity into account (Wulf 2010, 2013). This anthropological knowledge must include a reflection of its historicity and culturality, thus providing a frame of reference for education in such a way that the anthropological perspective is included. If we are to grasp the situation of human beings adequately today, we also need, for example, to understand the historical and cultural coordinates of globalization.

Living conditions in the 21st century are strongly influenced by the struggle between the uniformity of globalization and movements which emphasize cultural difference and diversity. This includes the conflicts between the global and the local, the universal and the singular, tradition and modernity, the spiritual and the material, necessary competition and equal opportunities, short-term and long-term reflections, the rapid spread of knowledge and the limitations of our human capacity to cope with this (Delors 1996; VENRO 2009).

In order to be able to deal competently with cultural diversity, we need to experience the Other. Neither people nor cultures can develop satisfactorily if they cannot mirror themselves in others, if they do not engage and influence each other. Both cultures and individuals are formed through exchange with others. Reciprocal exchange processes allow relationships to develop between people and broaden the 
horizons of their lives and experience in the process.

In education, it is important to create an awareness of the fact that European cultures have developed three strategies to reduce alterity to the known and trusted. One of these is Western rationality - logocentrism - which has led to foreign cultures and people being judged according to their adherence to logocentric norms. Whenever other cultures fail to live up to this expectation, they are degraded and not regarded as being of equal value. The second strategy centers on Western individuality and the egocentrism that goes with it. This egocentrism led to the development of a high esteem for the individual and an increase in individualist self-assertion at the cost of community. The third strategy employed to reduce alterity to Western standards is ethnocentrism, which has also led to an overvaluation of Western culture and a corresponding undervaluation of other cultures. The effects of these strategies are still apparent in the dynamics of globalization today and constitute an obstacle to dealing with cultural diversity fruitfully (Wulf/Merkel 2002; Wulf 2006). If students become aware of these mechanisms, they might gain the ability to reduce their impact on the perception of the Other.

In education, students have to become aware that in many areas, processes of contact, encounter and exchange are determined by the circulation of capital, products, the workforce and symbolic goods. The dynamics of these processes lead to meetings between people and cultures and engender both material and immaterial relationships. They occur within the framework of global power structures and are intrinsically unequal, being determined by consolidated power relationships that have their roots in history. Despite the fact that many such processes are influenced by capitalist market movements and therefore fuel inequality, they also promote encounters with the alterity of other people and cultures.

Societies and cultures are constituted by contact with alterity. To experience other people and cultures is central to the development of children and adolescents. People can only understand themselves as reflected by and through the reactions of other human beings and cultures. This implies that knowing ourselves means that we must be aware that there are limits to our understanding of alterity. How is it possible to accept one's experiences of other people without triggering mechanisms that reduce them to the known and trusted? There are several answers to this question that differ depending on context. One way to bear the alterity of strangers is based on the experience of one's own foreignness, i.e., feeling surprised by one's own feelings and actions. Such events can promote flexibility and curiosity about the alterity of other people and cultures.

Thus, in order to be able to understand and engage with alterity, we need to experience our own foreignness. This experience constitutes a basis for developing the ability to think and feel from the perspective of the Other, where the engagement with the non-identical is of central importance. Such experiences can be expected to increase sensitivity and the readiness to be open to what is new and 
unknown. In turn, this results in a better ability to bear complex situations mentally and emotionally without acting out stereotypes. Obviously, these options for personal development can also be subverted into their opposites. In such cases, the encounter with cultural variation is met by violent action aimed at reducing difference to sameness. Because such efforts mostly fail, a vicious circle of constantly escalating violent action ensues, which results from mimetic processes of mutual imitation (Wulf 2005).

A consciousness of the non-identity of the subject constitutes an important prerequisite for openness toward the Other. In the confrontation with foreign cultures, with the other in one's own culture and with the foreign in oneself, the capability is to be developed to perceive and think from the perspective of the Other. This change in perspective makes it imperative to avoid the reduction of the foreign to the own. An attempt is to be made at suspending the own and experiencing it from the perspective of the Other. The objective is the development of heterological thinking. Its focus is on the relationship of the familiar and the foreign, of knowing and not knowing, and of certainty and uncertainty. As a consequence of de-traditionalization and individualization as well as differentiation and globalization, many things taken for granted in daily life are called into question and require individual reflection and judgment. Nevertheless, the liberty accrued to the individual as a consequence of these developments does not represent a real gain in freedom. The individual often only has decision-making leeway in situations in which he or she has no control over the preconditions of the situation in which the decision is made. Regarding environment, for example, the individual is able to make conscious decisions, but he or she has little influence on the societal macrostructures that really determine the quality of the environment.

The increase in the inscrutability of the world leads to an increase in the $u n$ certainty of the individual, who must tolerate the difference between him- or herself and the Other. In this situation, uncertainty and insecurity become central characteristics of life in society. On the one hand, they originate in the world exterior to the person; on the other hand, they trace back to the interior of the person and ultimately to the interrelationship between the interior and exterior. Facing this situation, there are many attempts to make this uncertainty bearable through ostensive certainties. However, these certainties do not help to regain the lost security. Their validity is relative and arises primarily from the exclusion of alternatives. What is excluded is determined on the one hand by the psychological and social constitution of the individual and, on the other hand, by the societal power structures and processes of setting and excluding values, norms, ideologies and discourses. These processes often lead to the otherness of the Other not being noticed and the closing of the mind to the possibilities of perceiving and thinking from the perspective of the Other.

\section{Differentiation, Transgression, Hybridity}

Within the scope of globalized education, the terms differentiation, transfor- 
mation and hybrid formation play a central role in dealing with the foreign, the other and alterity. These terms are interrelated. Their interconnectedness is obvious (Audehm/Velten 2007). In education from a transcultural point of view, it is important to make use of these three concepts for the analysis of cultural phenomena and relations:

1) The concept of difference is important for creating boundaries and making a contribution to rendering them dynamic. It is not possible to form a national, cultural or European identity without differences. Thus, for example, in the processes of inclusion and exclusion that take place in rituals, differences are created which are crucial for the performative character of the rituals (Wulf et al. 2010). The category of difference also takes on a special importance for understanding alterity. The ways in which heterogeneity and alterity are dealt with are crucial to this cultural diversity, which is created by acts of differentiation (Wulf 2006).

2) For the analysis of social and cultural developments, it is important to understand processes of transgression. Transgression consists of overstepping the limits set by rules, norms and laws on the one hand, and overstepping historically created boundaries on the other. These acts of transgression can be non-violent, but they frequently also involve manifest structural or symbolic violence. In dealing with cultural diversity, boundaries are often transgressed, leading to the creation of something new. Transgressions change norms and rules, ways of life and practices. They change and shift borders and create new cultural relations and constellations in the process. In order to understand these processes, we need to make a thorough analysis of their contexts, focusing on the origin of the change or innovation in question.

3) To understand our own time, the analysis of new hybrid cultural forms by means of difference and transgression is a crucial issue. As communication and interaction between different countries become ever closer and faster, and economic, political, social and cultural exchange becomes more intensive, more and more hybrid cultural forms come into being. Homi Bhabha (2004) first used the term hybridization to define cultural contacts in a non-dualistic and non-essentialist way by describing them in terms of their function of creating identity by means of a "third space." The third space is liminal; it is a space in-between which emphasizes its own in-between-ness. In this liminal space, borders are subject to subversion and restructuring and hierarchies and power relationships are changed. The crucial questions are to what extent these processes result from performative practices and how these new forms of hybridization are created. They are mixed forms in which elements belonging to different systems and contexts change their character in a mimetic process, leading to a new cultural identity. This identity is no longer constituted by distinguishing oneself from another, but in mimetically assimilating oneself to the other.

It should be evident that only if the handling of cultural diversity is successful will it be possible to prevent wars and re- 
duce violence between people. Avoiding war and violent conflicts, i.e., creating and maintaining living conditions that are relatively free of violence, is the decisive prerequisite for successful human life. This is why education for peace is a central requirement of global learning.

\section{Education for Sustainable Development}

The analysis of violence with the objective of developing a commitment to forms of conflict resolution that are free of violence must be directed not only at other people, societies and cultures. A task not less important for the survival of humankind is analyzing violence exercised against nature and future generations through the consumption of non-renewable resources. Reducing this consumption by the development of education for sustainable development is part of that task. The aim of sustainable development is to realize a continuous process of all-encompassing social change which is to preserve the quality of life of the current generation while securing the options of future generations to create their own lives. Sustainable development has come to be recognized as a way of improving individual life chances and of promoting social prosperity, economic growth and ecological safety.

Agenda 21, ratified in 1992, led to the implementation of the world decade for sustainable development by UNESCO (2005-2014). The aims that were pursued in this decade differed according to world region. In Europe, working towards sustainability means first and foremost effecting an ecologically motivated change in the economic system. In less developed countries, the term is used mainly with reference to efforts to ensure the provision of basic services and education with the aim of catching up with the more developed countries. The goal of education for sustainability is to enable people to actively design an ecologically sane, economically productive and socially fair environment, taking global aspects into consideration (Wulf/Newton 2006).

Sustainability is a regulative idea. Like peace, it can never be fully realized. Sustainable education is an important prerequisite for the gradual realization of sustainability and sustainable development. As such, the teaching of history for education for sustainability is directed at the individuals whose sensitivity and responsibility it seeks to promote. To this end, it needs to start with existing structures and, always bearing in mind individual and social conditions, to develop the creative abilities of young people. By this I mean the ability to shape their own lives and their own environments in accordance with the premises of sustainable development. To do so, they need to be able to learn from concrete problems, study their contexts and prepare reflective action. Education for sustainability implies a reflective and critical understanding of education and a readiness to participate in relevant individual and social learning processes. To this end, minimal standards for studies of sustainable development need to be developed in accordance to the multiple perspectives of sustainability.

Education for sustainable development should contribute to the establishment of 
social justice regarding nations, cultures, world religions and generations. Alongside the promotion and refashioning of the environment and economic conditions, the central principles of sustainability also include global responsibility and political participation. With these goals, which go far beyond protection of the environment and its resources, the teaching of history for education for sustainability takes up ideas that were prepared in the 1970s (Wulf 1973, 1974). However, at that time there was little recognition of a need for social justice between generations and of the growing importance of the task of conserving non-renewable resources.

\section{Multimodality of Learning: New Perspectives of Transcultural Learning}

A learning oriented toward a better understanding of the Other and toward a reduction in violence against other people and future generations, will also have to develop innovative forms of learning. In a long-term perspective, an education for sustainability oriented toward peace and social justice leads to a far-reaching reform of the educational system. If one wants to at least partially realize these objectives which, due to their general and comprehensive nature, cannot be fully achieved, then this goal must also include changes in curricula and teaching methods. In teaching curricular areas that are important for these questions and for interdisciplinary integration of these perspectives into the education of the coming generation, it is not just a matter of mere conveyance of new content and knowledge. The objective is the empowerment of chil- dren through a fundamental shift in the perspective of education. This shift should not be limited to formal school education. A transcultural education for sustainability oriented toward peace and social justice is a continuous life-long task that is part of the formal educational system, professional education and continuing education as well as informal education.

Learning in a globalized world is multimodal (Kress 2009) and takes into account the following dimensions of learning (Delors 1996): learning to know, learning to do, learning to live with others, learning to be. The concept of multimodality refers to a learning taking place in many modes that must be taken into account. Only when this is successful does learning have lasting effects. Learning is synesthetic, meaning that it occurs not just through one sense, but through several senses. Images, sounds and touch play a central role. When development of language and imagination is at the center of learning, its foundation in the senses takes on great significance. Concepts are enhanced by perceptions and imagination can deal with material from the senses in a creative manner (Hüppauf/Wulf 2009).

In realizing a complex multimodal learning process, four perspectives play a prominent role: mimetic learning, performativity of learning, inquiry, i.e. explorative learning, and rituals of learning and communication.

\section{Mimetic Learning}

Mimetic learning is a basic form of cultural and transcultural multimodal learning. Mimetic learning involves the body 
and the senses. In transcultural learning, mimetic processes are directed at people, objects and facts of foreign cultures. In these processes, a "similarization" to the alterity of these non-self-contained cultures takes place. It occurs due to the fact that children take an impression, so to speak, from the representations of foreign cultures and integrate it into their imaginary (Hüppauf/Wulf 2009). Through mimetic processes, both an individual and a collective imaginary are created. Without mimetic representations, learning remains inanimate and does not enrich children's imaginaries (Wulf 2007; Gebauer/Wulf 1995). The students' mimetic learning relates to a foreign culture and to a teacher, whose method for examining, analyzing and interpreting foreign objects is imitated. In this process, the students do not just copy the teacher's interest and the way that he or she deals with the representations of a foreign culture. When children relate to the teacher mimetically, they develop their own approach to foreign cultures, to the other and to alterity using the teacher's behavior as a guide. The teacher's model of behavior is of major significance for the initiation and facilitation of the children's mimetic learning processes. Mimetic learning processes are not merely processes of copying; rather, they are creative processes of imitation in which an expansion of the everyday-environment takes place by having children relate to foreign people and the foreign world or other cultures in an autonomous manner. Mimetic processes not only refer to other people in face to face situations, but also to imaginary actions, scenes and themes. Without reference to the Other and to foreign cultures, children would not be able to develop adequately in social or in personal respects.

The fact that human beings differ from all other forms of life through their distinct mimetic abilities is something that was already recognized by Plato and Aristotle. This idea was further elaborated in an extensive anthropological study on the conception and history of mimesis (Gebauer/Wulf 1995) and on the significance of mimetic processes in the acquisition of culture (Gebauer/Wulf 1998, 2003). Recent studies in primate research have shown that infants of eight months already command mimetic competencies that are more advanced than those ever attained by primates (Tomasello 1999). Other recent studies on "mirror neurons" have shown that cognition of situations related to action display the same processes that can be observed during action itself (Rizzolatti/Craighero 2004; Iacoboni 2008). Last but not least, the "Berlin Study on Rituals" was able to show for all of the four central fields of socialization studied that mimetic processes are of central significance for pedagogy, education and learning (Wulf 2005; Wulf et al. 2004, 2007, 2010, 2011).

\section{Learning as a Performative Process}

When one speaks about the performativity of learning processes, the emphasis is on their enactment, their performance and their reality-constituting quality. The relationship between physical and symbolic action is studied. Research has focused on education and learning as processes of dramatic interaction, in which bodily and vocal action overlap, and where social scenarios and mimetically circulating processes of exchange are of prime im- 
portance; they can be studied by way of ethnographic methods. The focus on the performative nature of these processes implies an understanding of pedagogy as practical knowledge and therefore an interest in generating practical knowledge as a necessary means of pedagogic action.

Teaching and learning are not merely cognitive processes; they are also social processes in which interactions between students play a prominent role. In learning, bodily processes are more important than is generally perceived. An analysis of gestures in the context of interaction during instruction shows the extent to which learning and education are managed through facial expressions, gestures and posture (Wulf et al. 2011). Three aspects of the performativity or education are central in three explicit ways. Firstly, education is a historical and cultural performance. This means that depending on the historical and cultural context and the associated traditions of school culture, education differs in the different societies and cultures. To a large degree, these traditions determine which performative options exist for transcultural learning. Secondly, in education and learning, language is often performative and a mode of action. John Austin (1979) made this clear when he showed how important the performative character of speech is for communication and interaction. Hence, it is important to pay attention to this dimension in education. And thirdly, the performativity of education has a sensuous or aesthetic dimension that needs to be considered in the process of teaching and learning (Suzuki/Wulf 2007; Wulf/Zirfas 2007).

\section{Inquiry Learning}

A modern understanding of education does not only mean learning facts, but also learning how to learn, how to live together, how to act and how to be (Delors 1996). Learning can make an important contribution to the implementation in the school of an interdisciplinary mission that does not just convey subject-specific interrelationships of knowledge. For example, social life and the associated extracurricular experiences play an important role in the education of young people. In these processes, young people can learn to be independent and operate in a self-reliant manner with others in the community. Using the rituals of cooperative learning, students learn to rely on themselves to manage their learning processes. Ritualistic arrangements help here in the acquisition of practical knowledge regarding how to learn independently. Inquiry, i.e. explorative learning is of particular importance here. This form of learning strives during learning to learn how one learns. Inquiry learning requires time and a thorough examination of material to be discovered, structured and interpreted. This means integrating mimetic, performative and poietic modes of learning in order to create intensive learning experiences (Wulf 2003; Wulf et al., 2004, 2007, 2010, 2011; Werler/Wulf 2006; Suzuki/Wulf 2007).

\section{Rituals of Learning and Communication}

To a great extent, schools are ritual institutions. School rituals, therefore, also play an important role in transcultural learning. They range from singular celebrations to repetitive school macro rituals 
such as annual enrollment, graduation ceremonies and pre-Christmas events, to the numerous everyday-rituals in class that mark the passage between breaks and lessons and to the design, structure and sequence of the various learning cultures in class. Rituals constitute the social structures and functions and create communities in which children have their place. Apart from the symbolic content of their interaction and communication, the creation of community works by way of performative ritual practices that perform and enact community. Power relationships play a prominent role in the emergence of the order that these practices create. Through regularity and repetition, the relationships between children and between children and adults are confirmed as well as modified. Rituals and ritualizations have a beginning and an end. They are characterized by their dynamics, which cause adaptations and changes in child behavior. Their corporal practices create forms of action, images and schemata which children identify with, which they remember, and whose performance and enactment bring forth new forms of actions.

For the development of multimodal learning cultures in schools, rituals and ritualization play a central role. Learning as well as transcultural learning is understood as ritual action and accomplished as a collective task. With the aid of ritual arrangements, poietic and performative learning processes are initiated and support is provided for students' independence and self-control. Learning in school is understood as a social activity whose transcultural and gender-specific dimension receives particular attention. Ritual increases in flexibility can serve to transition from mere transfer of knowledge to poietic learning. In the open work situation of project teaching and in standardized situations of group conversations and lecture, the teaching and learning forms of traditional school rituals can be made more flexible. Methodologically, instruction can shift its main concern in this way from knowledge transfer to active learning. Softer and more flexible ritualizations that increase individual territorial, temporal, content-related and methodological latitude appear to make sense for this form of learning culture. These ritualizations support the socially oriented individual and advance the social semiotic approach to learning.

\section{Outlook}

Today, education makes a contribution to the development of cultural identity. In view of the diversity of cultures, this is a complex task. As a result of the standardizing tendency of globalization, recognition of cultural diversity and its competent handling are increasing in significance. Hence, members of the coming generations are encouraged to develop heterological thinking and a competence in dealing with the Other. In this way, education becomes intercultural education. For the creation and maintenance of living conditions free of violence and for an orientation of education toward the values of peace and sustainability, this is indispensable. Education is multimodal education, where mimetic convergence on the Other plays a central role. It is performative, attempts to promote forms of inquiry learning and uses school rituals for the promotion of implicit cultural knowledge. For 
the future of humankind, it is imperative to introduce into the educational system perspectives of an intercultural education for sustainability that is oriented toward the values of peace and social justice.

Address of the Author: Prof. Dr. Christoph Wulf, Freie Universität Berlin, Faculty Educational Science and Psychology, Head of the Department of Anthropology and Education, Arnimallee 11, 14195 Berlin, Germany.

Received: 2.Vl.2012

\section{References}

AUDEHM, K.NELTEN, R. (eds.) (2007) Transgression - Hybridisierung - Differenzierung: Zur Performativität von Grenzen in Sprache, Kultur und Gesellschaft (Freiburg, Rombach).

AUSTIN, J. L. (1979) Zur Theorie der Sprechakte (Stuttgart, Reclam).

BHABHA, H. K. (2004) The Location of Culture (London/New York, Routledge).

DELORS, J. (ed.) (1996): Learning - The Treasure within (Paris, UNESCO).

EDUCATION FOR ALL GLOBAL MONITORING REPORT (2011) The Hidden Crisis: Armed Conflict and Education (Paris: UNESCO).

FRIETERS-REERMANN, N. (2009) Friedens- und Konfliktpädagogik aus systemisch-konstruktivistischer Perspektive (Duisburg/Köln, WiKo-Verlag).

GALTUNG, J. (1973) Gewalt, Frieden und Friedensforschung. In: SENGHAAS, D. (ed.) Kritische Friedensforschung (Frankfurt/M, Suhrkamp).

GEBAUER, G., WULF, Ch. (1995) Mimesis. Culture, Art, Society (Berkeley, University of California Press).

GEBAUER, G, WULF, Ch. (1998) Spiel - Ritual - Geste. Mimetisches Handeln in der sozialen Welt (Reinbek, Rowohlt).

GEBAUER, G. WULF, Ch. (2003) Mimetische Weltzugänge. Soziales Handeln - Rituale und Spiele - ästhetische Produktionen (Stuttgart, Kohlhammer).
HÜPPAUF, B. WULF, Ch. (eds.) (2009) Dynamics and Performativity of Imagination. The Image between the Visible and the Invisible (New York, Routledge) (German edition 2006).

IACOBONI, M. (2008) Mirroring People: The new science of how we connect with others (New York, Farrar, Straus and Giroux).

KRESS, G. (2009) Multimodality. A social semiotic approach to contemporary communication (New York, Routledge).

RIZZOLATTI, G./CRAIGHERO, L. (2004) The Mirror-Neuron System, Annual Review of Neuroscience 27, pp. 169-192.

SENGHAAS, D. (ed.) (1995) Den Frieden denken. Si vis pacem, para pacem (Frankfurt/M, Suhrkamp).

SENGHAAS, D. (ed.) (2000) Frieden machen (Frankfurt/M., Suhrkamp).

STEVENSON, N. (2003) Cultural Citizenship. Cosmopolitan Questions. Issues in Cultural and Media Studies (Berkshire, Open University Press).

SUZUKI, S., WULF, Ch. (eds.) (2007) Mimesis, Poiesis, Performativity in Education (Münster/New York, Waxmann).

TOMASELLO, M. (1999) The Cultural Origins of Human Cognition (Cambridge/Mass, Harvard University Press).

UNESCO (2003) Convention on Intangible Cultural Heritage (Paris, UNESCO).

UNESCO (2005) Convention on the Protection of the Diversity of Cultural Expressions (Paris, UNESCO).

VENRO (Verband Entwicklungspolitik deutscher Nichtregierungsorganisationen e.V.) (2009) Global Learning, Weltwärts and Beyond. Global Perspectives on Education for Sustainable Development. Conference Report and Collection of Essays (Bonn: VENRO).

WERLER, Th., WULF, Ch. (eds.) (2006) Hidden Dimensions of Education (Münster/New York, Waxmann).

WULF, Ch. (ed.) (1973) Kritische Friedenserziehung (Frankfurt/M., Suhrkamp).

WULF, Ch. (ed.) (1974) Handbook on Peace Education (Oslo/Frankfurt/M, International Peace Research Association, Education Committee). 
WULF, Ch. (2002) Anthropology of Education (Münster/New York, Lit).

WULF, Ch. (2003) Educational Science: Hermeneutics, Empirical Research, Critical Theory (Münster/New York, Waxmann).

WULF, Ch. (2005) Zur Genese des Sozialen. Mimesis, Performativität, Ritual (Bielefeld, Transcript).

WULF, Ch. (2006) Anthropologie kultureller Vielfalt (Bielefeld, Transcript).

WULF, Ch. (2007) Une anthropologie historique et culturelle. Rituels, mimésis sociale, performativité (Paris, Téraèdre).

WULF, Ch. (2008) Friedenskultur/Erziehung zum Frieden, in GRASSE, R., GRUBER, B., GUGEL, G. (eds.) Friedenspädagogik: Grundlagen, Praxisansätze, Perspektiven (Reinbek, Rowohlt), pp. 35-60.

WULF, Ch. (ed.) (2010) Der Mensch und seine Kultur. Menschliches Leben in Gegenwart, Vergangenheit und Zukunft (Köln, Anaconda).

WULF, Ch. (2012) Anthropology. A Continental Perspective (Chicago, Chicago University Press).

WULF, Ch. et al. (2004) Bildung im Ritual. Schule, Familie, Jugend, Medien (Wiesbaden, Verlag Sozialwissenschaften).

WULF, Ch. et al. (2007) Lernkulturen im Umbruch. Rituelle Praktiken in Schule, Medien, Familie und Jugend (Wiesbaden, Verlag Sozialwissenschaften).

WULF, Ch., et al. (2010) Ritual and Identity. The Staging and Performing of Rituals in the Life of Young People (London, Tufnell).

WULF, Ch. et al. (2011) Die Geste in Erziehung, Bildung und Sozialisation (Wiesbaden, Verlag Sozialwissenschaften).

WULF, Ch., KAMPER, D. (eds.) (2002) Logik und Leidenschaft (Berlin, Reimer).

WULF, Ch., MERKEL, Ch. (eds.) (2002) Globalisierung als Herausforderung der Erziehung. Theorien, Grundlagen, Fallstudien (Münster,New York, Waxmann).

WULF, Ch., NEWTON, B. (eds.) (2006) Desarrollo Sostenibile (Münster,New York, Waxmann).
WULF, Ch., WEIGAND, G. (2011) Der Mensch in der globalisierten Welt. Anthropologische Reflexionen zum Verständnis unserer Zeit. Christoph Wulf im Gespräch mit Gabriele Weigand (Münster, Waxmann).

WULF, Ch., ZIRFAS, J. (eds.) (2007) Die Pädagogik des Performativen. Theorien, Methoden, Perspektiven (Weinheim,Basel, Beltz).

\section{Summary:}

\section{Human Development in a Globalized World. Education towards Peace, Cultural Diversity and Sustainable Development.}

Human development in a globalized world needs education towards peace, cultural diversity, and sustainable development. First, education for peace must draw on central guiding ideas such as the gradual reduction of manifest and structural violence and improvement of social justice. Second, the competence to cope with cultural diversity has to be developed in the globalized world. The third task important for the survival of humankind consists of analyzing and reducing violence exercised against nature and future generations through the consumption of non-renewable resources. Education for sustainable development has come to be recognized as a way of improving individual life chances and of promoting social prosperity, economic growth and ecological safety. Learning is multimodal and takes into account the following dimensions of learning: learning to know, learning to do, learning to live with others, learning to be. The concept of multimodality makes it clear that learning takes place in many modes that must be taken into account. Only when this is successful does learning have lasting effects. Mimetic learning in- 
volves the body and the senses. In transcultural learning, mimetic processes are directed at people, objects and facts of foreign cultures. In these processes, a "similarization" to the alterity of these non-selfcontained cultures takes place. When one speaks about the performativity of learning processes, the emphasis is on their enactment, their performance and their reality-constituting character. The focus is on knowledge of action and there is an interest in generating practical knowledge as a condition of pedagogic action. Inquiry learning requires time and a thorough examination of material that needs to be discovered, structured and interpreted. This means integrating mimetic, performative and poietic modes of learning in order to create intensive learning experiences. To a great extent, schools are ritually organized institutions. School rituals, therefore, also play an important role in transcultural learning.

Key Words: globalized world, peace's education, cultural diversity, sustainable development.

\section{Resumen:}

\section{Desarrollo humano en un mundo glo-} balizado. Educación para la paz, diversidad cultural y desarrollo sostenible.

El desarrollo humano en un mundo globalizado necesita educación para la paz (1), la diversidad cultural (2) y el desarrollo sostenible (3). En primer lugar, la educación para la paz debe basarse en ideas directrices centrales, tales como la reducción gradual de la violencia manifiesta y estructural y la mejora de la justicia social. En segundo lugar, la competencia para hacer frente a la diversidad cultural ha de desarrollarse en el mundo globalizado. La tercera tarea importante para la supervivencia de la humanidad consiste en el análisis y reducción de la violencia ejercida contra la naturaleza y las generaciones futuras a través del consumo de recursos no renovables. La educación para el desarrollo sostenible ha llegado a ser reconocida como una forma de mejorar las oportunidades de vida individuales y de promoción de la prosperidad social, el crecimiento económico y la seguridad ecológica. El aprendizaje es multimodal y debe tener en cuenta las siguientes dimensiones: aprender a conocer, aprender a hacer, aprender a vivir con los demás, aprender a ser. El concepto de multimodalidad, deja claro que el aprendizaje se lleva a cabo de muchos modos que deben ser tomados en cuenta. Sólo cuando esto tiene éxito, aprender tiene efectos duraderos. El aprendizaje mimético implica el cuerpo y los sentidos. En el aprendizaje transcultural, los procesos miméticos están dirigidos a personas, objetos y hechos de culturas extranjeras. En estos procesos, se lleva a cabo una similitud a la alteridad de estas. Cuando se habla de la performatividad de los procesos de aprendizaje, se hace hincapié en su promulgación, su rendimiento y su carácter de realidad constituyente. La atención se centra en el conocimiento de la acción y hay un interés en la generación de conocimiento práctico como condición para la acción pedagógica. La Investigaciónaprendizaje requiere tiempo y un examen completo del material que necesita ser descubierto, estructurado e interpretado. Esto significa la integración de los modos miméticos, performativo y poiético de aprendizaje con el fin de crear intensas

(2) 
experiencias de aprendizaje. En gran medida, las escuelas e instituciones están ritualmente organizadas. Los rituales escolares, por tanto, también desempeñan un papel importante en el aprendizaje transcultural.

Descriptores: mundo globalizado, educación para la paz, diversidad cultural, desarrollo sostenible. 